\title{
ECOLOGY OF TRICHINELLOSIS TRANSMISSION IN THE VORONEZH STATE NATURE RESERVE AND ADJACENT AREAS, RUSSIA
}

\author{
Boris V. Romashov ${ }^{1,2, * \mathbb{D}}$, Irina M. Odoevskaya ${ }^{3, * *} \mathbb{D}$, Natalya B. Romashova ${ }^{2, * * *} \mathbb{D}$, Nona A. Golubova ${ }^{1}$ \\ ${ }^{1}$ Voronezh State Agrarian University named after Emperor Peter the Great, Russia \\ ${ }^{2}$ Voronezh State Nature Biosphere Reserve, Russia \\ *e-mail:bvrom@rambler.ru,***e-mail:bvnrom@rambler.ru \\ ${ }^{3}$ K.I. Skryabin and Y.R. Kovalenko All-Russian Scientific Research Institute \\ of Experimental Veterinary Medicine of RAS, Russia \\ **e-mail: odoevskayaim@rambler.ru
}

Received: 12.05.2020. Revised: 22.01.2021. Accepted: 08.02.2021.

\begin{abstract}
The article considers certain aspects of the morphology and biology of Trichinella, and the ecology and epizootology of trichinellosis in the Voronezh State Nature Reserve and its adjacent areas (Black Soil Region of Russia). Original data were collected during 30 years (1990-2019) from potential hosts of Trichinella, mainly carnivorous mammals. During this period, more than 200 specimens of wild and domestic carnivores of three families (Canidae, Mustelidae, Felidae) were studied. Six species of wild carnivores (Canis lupus, Vulpes vulpes, Nyctereutes procyonoides, Meles meles, Martes martes, and M. foina) were obligatory hosts. In addition, Trichinella was found in Erinaceus concolor and two species of domestic carnivores (Canis lupus familiaris and Felis catus). The highest prevalence of infection was observed in Vulpes vulpes, Nyctereutes procyonoides, Meles meles, and Martes martes (35.7-70.0\%). These hosts play a leading role in the natural trichinellosis transmission. The carnivores can be divided into two groups according to the intensity of infection by Trichinella larvae per gram of muscles (lpg). The first group includes native carnivore species (Vulpes vulpes, Canis lupus, Meles meles, Martes martes, and M. foina), with an average of $10 \mathrm{lpg}$. The second group includes introduced species (Nyctereutes procyonoides) and invasive species (immigrants) from anthropogenic areas (Felis catus), with an average of $700 \mathrm{lpg}$. Due to its high pathogenicity, Trichinella can be considered as a significant factor in regulating the number of alien carnivorous species. Trichinella is also characterised by aggregated distribution in the muscles. In the Voronezh State Nature Reserve, the highest lpg values were observed in the muscles of the front and rear limbs of the carnivores. Over $50 \%$ of the local hemipopulation of Trichinella is concentrated in these muscle types. Based on the assessment of the morphological features of the Trichinella capsules and larvae from carnivores, two clusters of T. nativa hosts were identified. These clusters comprise carnivorous species that have closer trophic relationships. The variability of quantitative and qualitative parameters in the hosts indirectly reflects the specifics of the relationships in the host-parasite system and shows nutritional preferences of the studied carnivores. In the Voronezh State Nature Reserve and its adjacent areas, Vulpes vulpes is the main link in the stable transmission of trichinellosis. Vulpes vulpes has high rates of infection intensity (35.7\%) and large hemipopulations of Trichinella larvae (3.3 million specimens). Vulpes vulpes is the most abundant carnivorous species in the Voronezh State Nature Reserve and the most common hunting prey. So it can be used for monitoring the trichinellosis in European Russia. In the Voronezh State Nature Reserve, invertebrate animals can also contribute to the trichinellosis transmission. Carabid beetles (Carabidae) were registered as the disseminators of $T$. nativa. At present, in the Voronezh State Nature Reserve and in its adjacent areas, trichinellosis is transmitted by wild carnivores. The dominant position in the parasitic system of T. nativa is occupied by Vulpes vulpes. The other Carnivora species are subdominant. The specifics of the trichinellosis transmission and Trichinella transmission factors depend on the trophic relationships between animal hosts. The main forms of trophic relationships between carnivores are predation, necrophagy and cannibalism. Erinaceus concolor and insects (Carabidae) may also contribute to the preservation and dissemination of Trichinella.
\end{abstract}

Key words: infection prevalence, morphometry, natural ecosystems, population structure, shape index, Trichinella nativa, Vulpes vulpes, wild carnivores

\section{Introduction}

Trichinellosis is a zoonotic disease, i.e. a disease affecting both humans and animals. It is very widespread and presents a serious social and general biology problem (Britov, 1982; Gajadhar \& Gamble, 2000; Pozio, 2007). The causative agent of trichinellosis was discovered about 150 years ago, although its pathology in humans had been known long before. In any case, the co-evolution of people and Trichinella began when humans started eating animals. In other words, the evolution of trichinellosis as a zoonosis proceeded simultaneously with human evolution (Boev, 1978; Britov, 1982; Zarlenga et al., 2006). Trichinellosis is mainly spread via two transmission cycles, natural and synanthropic (Britov, 1975; Boev, 1978; Pozio, 2001; Pozio \& 
Zarlenga, 2005; Pozio \& Murrell, 2006), with the natural cycle prevailing (Pozio, 2000, 2001). There are a large number of studies on trichinellosis as a natural focal infectious disease, and the geography of research in this field is constantly expanding.

Trichinella is found in over 100 vertebrate species, mainly mammals, as well as in reptiles and birds. Until recently, the genus Trichinella was represented by a single species, Trichinella spiralis Owen, 1835. In the 1970-1980s, Britov (1982) contributed to identify four nominal species of Trichinella. Now, 12 Trichinella species are recognised based on the results of molecular-genetic testing (Murrell et al., 2000; Pozio \& Zarlenga, 2005; Pozio \& Murrell, 2006). They infest various species and groups of vertebrates. The parasites are either cosmopolitans (T. spiralis and T. pseudospiralis Garkavi, 1972) or occupy certain zoogeographic or continental regions (Trichinella nativa Britov \& Boev, 1972, T. britovi Pozio, La Rosa, Murrell \& Lichtenfels, 1992, T. murrelli Pozio \& La Rosa, 2000, T. nelsoni Britov \& Boev, 1972, T. papuae Pozio et al., 1999, T. zimbabwensis Pozio et al., 2002, and Trichinella sp. T6, T8, T9 and Trichinella sp. T12). Trichinella nativa was found in the Voronezh State Nature Reserve.

Now, four Trichinella species are known in Europe, including T. nativa and T. britovi characterised by high incidence rates, and T. spiralis and T. pseudospiralis, which are sporadic (Pozio, 2000; Pozio \& Murrell, 2006). Trichinella spiralis is spread via the synanthropic cycle largely involving Sus scrofa domestica Linnaeus, 1758 (Pozio \& Zarlenga, 2005). Trichinella nativa is more widespread in the arctic and subarctic regions of Europe, Asia and North America. In Russia, T. nativa was registered in the regions with a cold climate, including the central part of European Russia, Siberia, and the Russian Far East (Britov, 1982; Pozio et al., 2001; Romashov et al., 2006; Gajadhar et al., 2009; Bukina \& Odoevskaya, 2013; Odoevskaya et al., 2013; Tulov et al., 2013; Solovieva et al., 2017; Andreyanov \& Konyaev, 2018). It is also common in the North European countries (Murrell et al., 2000; Pozio, 2001; Oivanen et al., 2002; Airas et al., 2010; Asbakk et al., 2010; Isomursu \& Kunnasranta, 2011).

Trichinella britovi is found in regions with moderate climate, in Eastern and Western Europe, Asia, and North and West Africa (Pérez-Martín et al., 2000; Pozio, 2001; Schynts et al., 2006; Malakauskas et al., 2007; Blaga et al., 2008; Szell et al., 2008; Beck et al., 2009; Blaga et al., 2009; Frey et al., 2009; Gajadhar et al., 2009; Hurníková \& Du- binský, 2009). Trichinella nativa and T. britovi occur mainly under natural conditions and occupy different areas depending on the climate. The January isotherm of $-4^{\circ} \mathrm{C}$ is the southern boundary of $T$. $n a-$ tiva distribution, while the January isotherm of $-6^{\circ} \mathrm{C}$ is the northern boundary of $T$. britovi distribution (Pozio \& Murrell, 2006).

A particular role in the transmission of trichinellosis belongs to invertebrates involved in scavenging of carnivore carcasses. They contribute to the infective larvae transmission and act as disseminators of Trichinella. Certain species and groups of invertebrates can swallow Trichinella larvae and preserve them for a long time (Odoevskaya, 2011; Bukina, 2012c, 2014; Bukina et al., 2012; Bukina \& Igitova, 2013; Zimmerman, 1970; Hulebak, 1980; Maroli \& Pozio, 2000; Odoevskaya et al., 2013; Riva et al., 2015). Given the considerable proportion of insects in the diet of insectivores and carnivores, the possibility of the Trichinella transmission through insects is relatively high. The role played by insects involved in scavenging animal carcasses can be demonstrated by experimental studies. For example, larvae of Lucilia sericata Meigen, 1826 and species of Sarcophaga Meigen, 1826, and necrophagous larvae of Dermestes maculatus De Geer, 1774 are able to swallow Trichinella larvae and maintain their viability for several days. This increases the possibility of parasite transmission by arthropods in the wild (Maroli \& Pozio, 2000; Riva et al., 2015).

Trichinella-infected larvae of insects can be found on the ground and become food for Insectivora species, which are registered as hosts of Trichinella too (Pozio \& Murrell, 2006). As a result, the number of hosts for this nematode increases. Pozio (2001) described the infection process of herbivorous mammals feeding on pastures where there were carcasses of animals infected with Trichinella larvae. A high reproductive ability was also observed in Trichinella extracted from insect larvae, when used in the experiments on laboratory mice (Maroli \& Pozio, 2000).

Therefore, the possibility of Trichinella transmission by insects is relatively high, given that they are an important element of the diet of insectivores and carnivores. Earlier, Zimmerman (1970) described mechanical transmission of Trichinella by necrophagous insects and demonstrated that this process could contribute greatly to the epidemiology of trichinellosis. Now, a growing number of studies focuses on the role of these insects as paratenic hosts. This is a major way for the $T$. spiralis transmission, since after rodent control activities, car- 
casses of dead rodents remain close by pig farm, and paratenic hosts can easily disseminate Trichinella among domestic and wild animals (Pozio, 2007).

Currently, the epidemic and epizootic situation associated with trichinellosis is rather tense. The distribution areas of Trichinella tend to grow all over the world (Gajadhar \& Gamble, 2000; Pozio, 2007), including Russia (Uspensky, 2004, 2007; Bukina \& Odoevskaya, 2013). Trichinellosis is of current concern in European Russia including the Black Soil Region (Moskvitin et al., 2006; Romashov et al., 2006; Vagin et al., 2011). In the Black Soil Region, the first studies on trichinellosis were conducted by Merkushev $(1955,1965)$ and continued by Romashov (1959), Romashov et al. (1980). They gathered the information regarding the infection spread in wild animals in the region. More recent studies demonstrated that the first cases of endemic human trichinellosis in the Voronezh Region were assigned to ingestion of badger meat, as Meles meles Linnaeus, 1758 is a hunting species in this area (Romashov et al., 2003a,b). Special genetic studies conducted earlier determined that one species of Trichinella, T. nativa, is found in the Carnivora populations in the Voronezh State Nature Reserve and its adjacent areas (hereinafter VSNR) (Romashov et al., 2006). Recent molecular genetic tests confirmed that «Voronezh»'s Trichinella belongs to T. nativa (Odoevskaya \& Spiridonov, 2016). This species is characterised by small reproduction potential in females (due to a short uterus), low adaptation to Rattus, Sus scrofa Linnaeus, 1758 and high resistance to freezing (Britov, 1982; Kapel, 2000; Odoevskaja et al., 2009).

Trichinella has an «economical» (direct) life cycle. A single host organism combines the functions of the definitive and intermediate hosts, i.e. the phenomenon of amphixenia is observed (Sudarikov, 1971; Pozio, 2007). As a result, two Trichinella groups are formed in the host at the same time, i.e. imaginal and larval hemipopulations. Within a single host, they are defined as local hemipopulations, which successively replace one another. The first life cycle stage is the formation of an imaginal hemipopulation after the invasive larvae enter the host organism. The second stage is the formation of the larval Trichinella hemipopulation by migration of the larvae and their encapsulation into muscles. Fig. 1 shows a scheme of the population structure and the life cycle of Trichinella, where all stages of the development of the nematode proceed in the endogenous environment, i.e. in the definitive (= intermediate) host (Fig. 1).

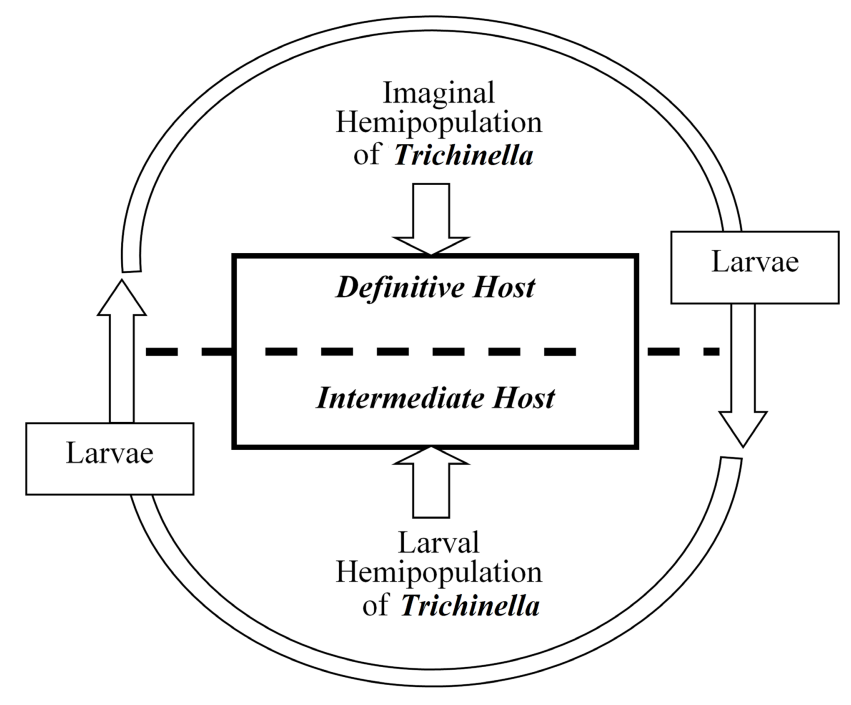

Fig. 1. Population relationships in the structure of the life cycle of Trichinella (Romashov et al., 2006 as amended).

Today, it is important to study the trichinellosis transmission into the natural environment in the forest-steppe conditions of the centre of European Russia. We collected new material on trichinellosis under similar conditions, focusing primarily on the data from the Voronezh State Nature Reserve. In this regard, the obtained results will be of great practical interest. This material will be able to characterise the distribution, transmission process and epizootology of trichinosis in the study area. This will enable us to assess the epidemic risks associated with this infection.

We aimed to study certain aspects of the morphology and biology of Trichinella, and the ecology and epizootology of trichinellosis under natural conditions in the Black Soil Region, represented by the VSNR. For this purpose, we performed the following tasks: a) to study the morphological and taxonomic features of the local Trichinella species; b) to estimate the Trichinella larvae distribution in the host's muscles and assess the local hemipopulation of Trichinella; c) to study the ecological and biological patterns of the trichinellosis transmission and the formation of an ecological model of trichinellosis in the study area.

\section{Material and Methods}

The material was collected in the VSNR (between $51.083^{\circ} \mathrm{N}$ and $52.0^{\circ} \mathrm{N}$ and between $39.033^{\circ} \mathrm{E}$ and $39.083^{\circ} \mathrm{E}$ ). The Voronezh State Nature Reserve is located in the central part of the Black Soil Region. This is a predominantly forest-steppe area, with vast steppe areas combined with forest outliers. The area of the Voronezh State Nature Reserve is $320 \mathrm{~km}^{2}$. The Protected Area is almost completely 
covered by forest. It occupies the northern half of the Usman forest, one of the largest forest outliers in the Black Soil Region. The adjacent areas occupy the southern half of the Usman forest $\left(280 \mathrm{~km}^{2}\right)$. The Voronezh State Nature Reserve borders with natural and agricultural areas, as well as two administrative regions (Voronezh Region and Lipetsk Region) and five districts (Verkhnekhavsky district, Ramonsky district, Novousmansky district, Usmansky district, and Voronezh urban area).

During the study, we processed and analysed original material collected over 30 years (1990 2019) in the VSNR from potential Trichinella hosts, mainly carnivores, and some Insectivora species (e.g. Erinaceus concolor Martin, 1838). More than 200 specimens of wild and domestic carnivores (Carnivora) of three families (Canidae, Mustelidae and Felidae), belonging to 12 species, were studied, including Canis lupus Linnaeus, 1758 (34 specimens), Vulpes vulpes Linnaeus, 1758 (157 specimens), Nyctereutes procyonoides Gray, 1834 (ten specimens), Meles meles (eight specimens), Martes martes Linnaeus, 1758 (14 specimens), M. foina Erxleben, 1777 (12 specimens), Neovison vison Schreber, 1777 (19 specimens), Lutra lutra Linnaeus, 1758 (two specimens), Mustella eversmanni Lesson, 1827 (one specimen), Mustela nivalis Linnaeus, 1766 (six specimens), $\mathrm{Ca}$ nis lupus familiaris, Linnaeus, 1758 (30 specimens), Felis catus Linnaeus, 1758 (18 specimens). In the Voronezh State Nature Reserve, the material was obtained from living host animals during control activities, as well as from dead animals. In the adjacent areas, material was obtained from carnivores brought by hunters (in areas where hunting is allowed) and from dead animals (mostly the ones killed by cars in traffic). More than 2000 specimens of Sus scrofa were studied on Trichinella larvae in the Voronezh State Nature Reserve in the 1980-1990s.

We diagnosed and detected Trichinella sp. larvae in the muscle tissue using trichinelloscopy and artificial digestion (Vladimirova, 1965; Gamble et al., 2000). The prepared material (compressorium and watch glasses) were examined using MBS-10 and Motic SMZ161-TLED microspores at a magnification of $10-45 \times$. The relative size of the local hemipopulation of Trichinella (in one host) was calculated by the number of larvae per 1 gram (lpg) of the muscle tissue (relative intensity of infection).

We investigated the distribution of T. nativa larvae in various muscle groups of carnivores. These data were obtained in the VSNR from four carnivore species (Vulpes vulpes, Nyctereutes procyonoides, Martes martes, and Felis catus). We took a 1-g sample from each muscle and counted the number of larvae in them. Forty skeletal muscles combined into six groups were examined using trichinelloscopy.

Based on the relative Trichinella number in the muscles of an individual host, we can determine the size of local hemipopulations (Fig. 1). This indicator allows us to calculate the approximate size of the Trichinella hemipopulation in the population of a certain host species per limited area. The size of Trichinella hemipopulations in the host population can be calculated by multiplying three factors, namely 1) the size of the local larvae hemipopulations, 2) Trichinella incidence index, and 3) the number of host individuals (Galaktionov \& Dobrovolsky, 1998).

By parasitising on various hosts, Trichinella demonstrates morphological variations in larvae (organs and structures) and capsules (shape and size). We studied Trichinella larvae from six species of wild and domestic carnivores (Vulpes vulpes, $\mathrm{Ca}$ nis lupus, Nyctereutes procyonoides, Martes martes, Meles meles, and Felis catus). Trichinella capsules have a rounded or slightly elongated shape. The capsule walls are relatively thick with a larva inside staying in a helically coiled form. The capsule shape was evaluated using the shape index, i.e. the ratio of the capsule diametre to its length. A comparative morphological study of capsules and living Trichinella larvae was performed. For this purpose, temporary samples were prepared by placing the subjects on glass slides in normal saline. The diameter (D) and the length (L) of the capsules were measured. They were used to determine the shape index (V) of Trichinella capsules, calculated as a ratio of diameter to length $(\mathrm{V}=\mathrm{D} / \mathrm{L})$. This parameter is used in zoological studies to assess the shape of rounded objects, e.g. bird and helminth eggs (Kostin, 1977; Romashov \& Lomakin, 2000).

We carried out a comparative survey of Trichinella larvae morphometry from the Carnivora species of the study area. The measurement results are given in micrometers $(\mu \mathrm{m})$. Comparative morphometry of the larvae was based on 11 parameters, including the already known (body length $(\mu \mathrm{m})$, body width $(\mu \mathrm{m})$, number of stichocytes $(\mathrm{n})$, length of the muscular esophagus $(\mu \mathrm{m})$, length of the midintestine $(\mu \mathrm{m})$, length of the rectum $(\mu \mathrm{m})$, length of gonads $(\mu \mathrm{m})$ (Sokolova \& Shaikenov, 1976)), and the new (length of the trophic sensory part $(\mu \mathrm{m})$, length of the trophic reproductive part $(\mu \mathrm{m})$, length of the stichosome $(\mu \mathrm{m})$, distance from the beginning of the gonads to the caudal end $(\mu \mathrm{m})$ ). The results of pairwise comparison of Trichinella 
morphology were presented using the Student's ttest. We determined that the host pairs significantly differed in a certain set of parameters $(p<0.050$ 0.001 ). Morphological and morphometric studies of Trichinella were carried out using a BIOMED-6 light microscope (40-1000 × magnification).

In addition, we investigated some aspects of the Trichinella dissemination involving invertebrate animals in the Voronezh State Nature Reserve. We disposed of the corpses of Nyctereutes procyonoides infected by $T$. nativa. The insects died in the Voronezh State Nature Reserve as a result of trichinellosis infestation (more than 700 larvae per $1 \mathrm{~g}$ of muscle tissue (lpg)). The experimental conditions were as close as possible to natural ones. We collected insects (imago and larvae) from the Nyctereutes procyonoides corpses and examined them on Trichinella larvae.

In order to assess the infection rate and distribution of Trichinella larvae in the hosts, we used the following indices: the abundance index, the infection intensity index, and the infection prevalence (incidence) index. When considering the structure of the helminth (Trichinella) population and the relationships within it, we took into account the current concepts and used the adopted terminology according to Galaktionov \& Dobrovolsky (1998). Statistical data processing was performed using the software Statistica 5.5 (Statsoft, Tulsa, OK, USA) and Microsoft Excel 2013.

\section{Results}

In the VSNR, T. nativa was found in nine Carnivora species, including seven wild mammals (Vulpes vulpes, Nyctereutes procyonoides, Canis lupus, Meles meles, Martes martes, $M$. foina, and Erinaceus concolor) and two domestic carnivores $(\mathrm{Fe}$ lis catus and Canis lupus familiaris). The infection prevalence in wild mammals ranged from $8.3 \%$ to $70.0 \%$ (Fig. 2). These species have several levels of dominance. Typically, a small number of host species, one or two, play a key role in the Trichinella transmission. They are primarily the most numerous native Carnivora species. The highest infection prevalence was observed in four species (Martes martes, Meles meles, Nyctereutes procyonoides, and Vulpes vulpes). Other host animal species, including both native and alien species, occupy the other levels in the parasitic system of Trichinella, depending on the peculiarities of their ecology. Infection rates were much lower in Canis lupus and Martes foina. We should also note that Trichinella was found in Erinaceus concolor (Fig. 2).

We found a considerable difference between the relative number of Trichinella in the carnivores of the Voronezh State Nature Reserve and those on adjacent areas (Table 1). The number of larvae in Nyctereutes procyonoides was considerably higher than that in Vulpes vulpes, although both host species belong to the same family (Canidae) and have similar ecological preferences. Based on these data, we determine two population size variants depending on the host. In the first variant, the hosts are Vulpes vulpes and Martes martes with the average infection rates within $10 \mathrm{lpg}$, and in the other variant the hosts are Nyctereutes procyonoides and Felis catus with 600-700 lpg (Table 1).

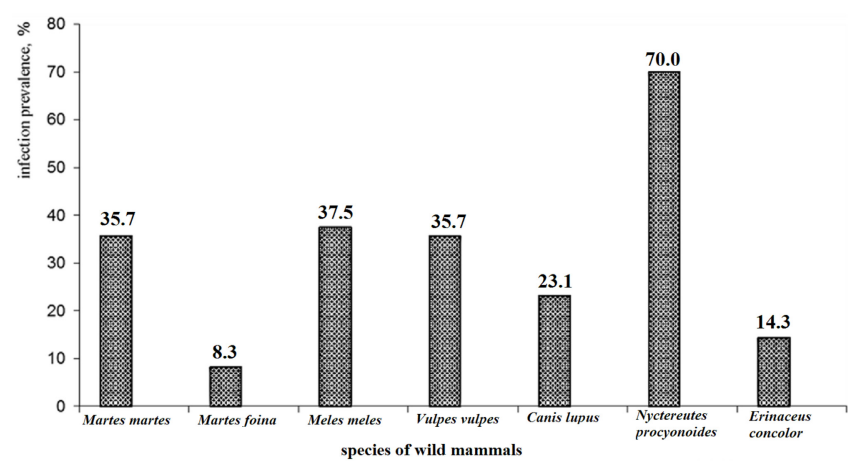

Fig. 2. Prevalence of Trichinella nativa infection in wild mammals in the Voronezh State Nature Reserve and its adjacent areas (Russia).

Table 1. Distribution of Trichinella nativa larvae in various muscle groups in four carnivore species in the Voronezh State Nature Reserve and its adjacent areas

\begin{tabular}{|c|c|c|c|c|c|}
\hline \multirow{2}{*}{ Groups of muscles } & \multirow{2}{*}{$\mathrm{N}$} & \multicolumn{4}{|c|}{ Average lpg in the muscle (minimum and maximum number) } \\
\hline & & Vulpes vulpes & Nyctereutes procyonoides & Martes martes & Felis catus \\
\hline Muscles of the head (I), lpg & 6 & $4.3(2-7)$ & $536.0(326-703)$ & $10.5(7-15)$ & $534.0(308-731)$ \\
\hline Muscles of the neck (II), lpg & 4 & $6.0(3-12)$ & $309.3(302-412)$ & $8.3(5-12)$ & $405.5(238-482)$ \\
\hline Muscles of the shoulder and foreleg (III), lpg & 6 & $12.6(7-19)$ & $1076.5(480-1870)$ & $15.7(8-24)$ & $870.3(552-1278)$ \\
\hline Trunk muscles (IV), lpg & 11 & $11.0(5-20)$ & $511.2(142-907)$ & $9.0(4-18)$ & $567.3(328-801)$ \\
\hline Muscles of the pelvic arch and hind leg (V), lpg & 12 & $10.9(3-23)$ & $954.6(551-1999)$ & $14.6(4-28)$ & $803.7(582-1207)$ \\
\hline Muscles of the tail (VI), lpg & 1 & $1.8(1-3)$ & $81.8(70-93)$ & $3.8(2-5)$ & $95.2(89-101)$ \\
\hline $\begin{array}{l}\text { Average number of larvae in the studied groups } \\
\text { of muscles, lpg }\end{array}$ & 40 & 9.4 & 702.1 & 11.7 & 650.8 \\
\hline
\end{tabular}

Note: $\mathrm{n}$ - number of examined muscles in each group (I-VI). 
We assume that such a great difference can be explained by the host specificity of Trichinella manifested in the host-parasite relationship system. We believe that carnivores are adapted to «local» Trichinella. In this regard they have developed congruent host-parasite relationships. On the contrary, predator species (Nyctereutes procyonoides and Felis catus), alien to the VSNR, do not have the necessary adaptive immune response to the «local» Trichinella. In these hosts, a significant increase in the size of local Trichinella hemipopulations (intensity of infection) was observed.

The distribution of T. nativa larvae in different groups of carnivore muscles is of aggregated nature, considering their absolute and relative numbers. A pairwise comparison of individual muscle groups showed significant $(\mathrm{p}<0.05-0.01)$ differences between these values. The highest relative number was observed in the muscle groups of the forelegs and hind legs (Table 1).

Similar ratio tendencies were observed for the larvae distributed in the muscles of Canidae (Vulpes vulpes and Nyctereutes procyonoides), Mustelidae (Martes martes) and Felidae (Felis catus). The ratios of the relative larvae number by muscle groups were calculated for these carnivores. The highest number of Trichinella was concentrated in the muscles of the shoulder girdle, foreleg, pelvis, and hind leg, followed by the head, neck, and trunk. The minimum number was registered in the tail muscles (Fig. 3).

The Trichinella circulation is accounted by the diversity and the number of host animals. In the VSNR, the number of carnivores determines the size of larval Trichinella hemipopulations. On the other hand, estimating the size of larval Trichinella hemipopulations in carnivore populations makes it possible to consider the role of certain carnivore species in the transmission of natural foci of $T$. $n a-$ tiva on a case-by-case basis.

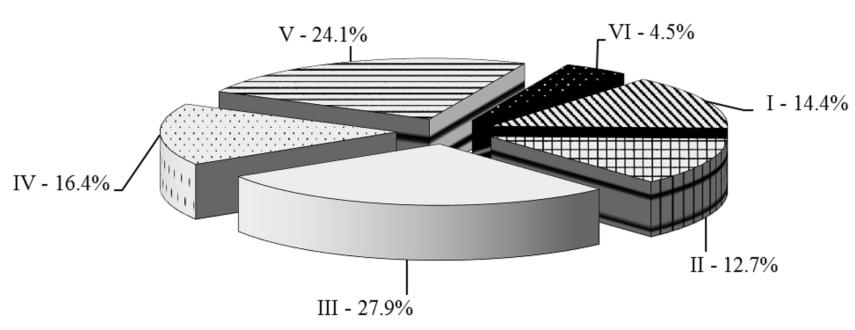

Fig. 3. Ratio of the relative number of Trichinella nativa larvae in the studied muscle groups in four carnivore species (Vulpes vulpes, Martes martes, Nyctereutes procyonoides, and Felis catus). The Roman numeration denotes the muscle groups: I - head, II - neck, III - shoulder and foreleg, IV trunk, V - pelvis and hind leg, VI - tail.
We performed a special measurement of the local Trichinella hemipopulation in Vulpes vulpes. The average relative number of Trichinella in $V$. vulpes muscles was 35.5 lpg. The average muscle mass of the sample was $2500 \mathrm{~g}$. By multiplying these values $(35.5 \times 2500=88750)$, we determined the size of the local Trichinella hemipopulation in $V$. vulpes (about 88750 larvae). Then, we calculated the size of Trichinella hemipopulations in the $V$. vulpes population in the whole Voronezh State Nature Reserve. In this Protected Area, the $V$. vulpes population currently consists of 104 individuals (according to the 2015-2019 data), while the Trichinella infection rate is $35.7 \%$ (index of prevalence is $0.357)$. By multiplying these values, the number of individuals per local hemipopulation $(88750 \times 104 \times 0.357=3295110)$, we obtained the size of Trichinella larvae hemipopulation in the $V$. vulpes population in the Voronezh State Nature Reserve. Such studies have not yet been conducted for other carnivores.

Therefore, based on the size of the local Trichinella hemipopulation, the incidence in host populations and their number, we can assess the role of a certain carnivore species in the trichinellosis transmission. Vulpes vulpes is the main driver in the Trichinella preservation and maintaining the stable trichinellosis transmission in the VSNR. First, $V$. vulpes demonstrated a relatively high prevalence of infection with Trichinella larvae (35.7\%). Second, V. vulpes is the most numerous carnivore species. Its abundance is currently several times higher than the abundance of other carnivores. The role of other Carnivora species in this process is low, taking into account the parameters of the infection rate (Fig. 2) and their number (according to the 2015-2019 data).

The data on the form index of Trichinella capsules in the studied Carnivora species are listed in Table 2. The largest capsules were detected in Felis catus and Nyctereutes procyonoides. In other studied hosts, the capsules were considerably smaller (Table 2). Based on the data obtained, the capsule shape index was calculated. It varied from 0.63 to 0.97 . Rounded capsules were observed in Felis catus, Nyctereutes procyonoides, and Vulpes vulpes. Elongated capsules were registered in Martes martes, Canis lupus, and Meles meles (Fig. 4). 
Table 2. Morphometric traits of Trichinella nativa capsules from six carnivore species in the Voronezh State Nature Reserve and its adjacent areas

\begin{tabular}{|c|c|c|c|}
\hline \multirow{2}{*}{ Host species } & $\mathrm{D}(\mathrm{n}=25)$ & $\mathrm{L}(\mathrm{n}=25)$ & $V(n=25)$ \\
\hline & \multicolumn{3}{|c|}{$\mathrm{M} \pm \mathrm{m}(\lim )$} \\
\hline Meles meles & $248.5 \pm 5.1(201.6-288.0)$ & $394.9 \pm 8.64(324.0-453.6)$ & $0.63 \pm 0.01(0.56-0.74)$ \\
\hline Martes martes & $258.2 \pm 7.44(187.2-316.8)$ & $369.6 \pm 5.89(324.0-396.0)$ & $0.70 \pm 0.02(0.54-0.87)$ \\
\hline Vulpes vulpes & $280.2 \pm 9.92(216.0-374.4)$ & $317.4 \pm 10.95(216.0-403.2)$ & $0.88 \pm 0.02(0.74-1.0)$ \\
\hline Canis lupus & $227.9 \pm 5.39(194.4-288.0)$ & $360.3 \pm 8.64(324.0-482.4)$ & $0.64 \pm 0.02(0.42-0.79)$ \\
\hline Nyctereutes procyonoides & $348.0 \pm 7.7(323.0-418.0)$ & $386.9 \pm 7.6(323.0-410.4)$ & $0.90 \pm 0.02(0.82-1.0)$ \\
\hline Felis catus & $443.4 \pm 5.6(380.0-475.0)$ & $458.5 \pm 5.5(418.0-494.0)$ & $0.97 \pm 0.01(0.86-1.0)$ \\
\hline
\end{tabular}

Note: $\mathrm{D}$ - capsule diameter, $\mu \mathrm{m} ; \mathrm{L}$ - capsule length, $\mu \mathrm{m} ; \mathrm{V}$ - shape index; $\mathrm{n}$ - number of the studied larvae from each host; $\mathrm{M}$ - mean value; $\mathrm{m}-$ error of the mean; lim - limits of values.

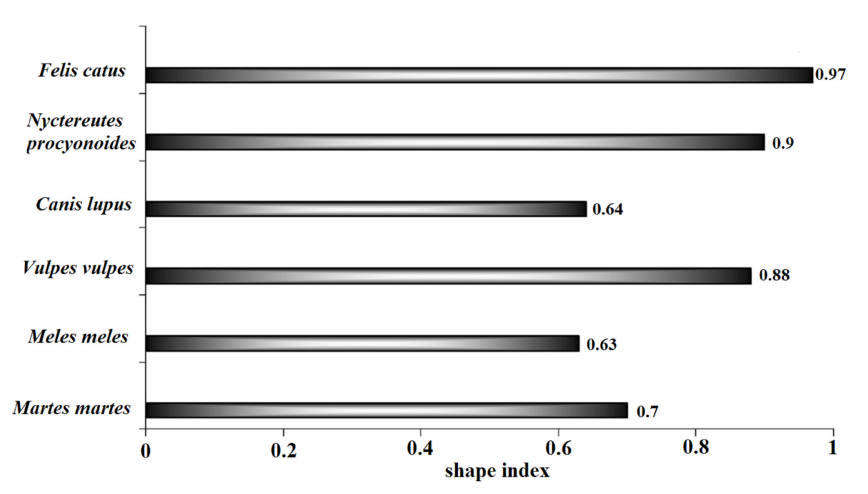

Fig. 4. Shape index of Trichinella nativa capsules from six carnivores species in the Voronezh State Nature Reserve and its adjacent areas.

The pairwise comparison of the capsules from different hosts demonstrated that in most of the compared pairs of carnivore species, the shape indices differed significantly $(\mathrm{p}<0.001)$. The only exceptions were the pairs Meles meles - Canis lupus and Vulpes vulpes - Nyctereutes procyonoides. For them, no significant differences in the shape index $(\mathrm{p}>0.05)$ were observed (Table 3). These results indirectly indicate close trophic relationships in these pairs. Therefore, we assume that Nyctereutes procyonoides is being infected with Trichinella via Vulpes vulpes, while Canis lupus via Meles meles. The comparative morphometry of Trichinella larvae by 11 parameters from the studied mammal species is presented in Table 4.

Significant differences were revealed among the larvae of the studied mammal species in pairwise comparison. The maximum differences (by 11 parameters) were recorded in Trichinella nativa larvae in the host pair Vulpes vulpes - Felis catus. Three pairs of hosts differ in 10 parameters: Martes martes - Felis catus, Nyctereutes procyonoides - Felis catus, and Canis lupus - Felis catus. Four pairs of carnivores differ in 9 parameters: Vulpes vulpes - Martes martes, Meles meles - Felis catus, Meles meles Vulpes vulpes, and Martes martes - Nyctereutes procyonoides. There are pairs that differ in 8, 7, and 6 parameters: Canis lupus - Martes martes, Meles meles - Nyctereutes procyonoides, and Meles meles - Canis lupus, respectively. A difference in five parameters was revealed in two pairs: Vulpes vulpes - Nyctereutes procyonoides and Vulpes vulpes - Canis lupus. A difference in four parameters was observed in Meles meles Martes martes and in two parameters in Canis lupus - Nyctereutes procyonoides.

We believe that the degree of variability of a particular parameter depends on the host species. The most significant difference, both in the number of parameters and in the variation degree, was noted in the pair Felis catus - Nyctereutes procyonoides. Thus, we can say that $T$. nativa is more adapted to the native host species (Vulpes vulpes, Canis lupus, Meles meles, and Martes martes) than to the alien species (Nyctereutes procyonoides and Felis catus). Therefore, Trichinella larvae should exhibit higher pathogenicity for alien host species, Nyctereutes procyonoides and Felis catus.

The complex joining method was used to analyse $T$. nativa larvae by 12 parameters (including the capsule shape index). The analysis identified six Trichinella morphs representing the individual characteristics for each carnivore host species, and two relatively independent clusters of host eco-forms. The first cluster included two Mustelidae species (Martes martes and Meles meles) and one Canidae species ( $\mathrm{Ca}$ nis lupus). The second cluster was formed by two Canidae species (Vulpes vulpes and Nyctereutes procyonoides) and one Felidae species (Felis catus) (Fig. 5). 
Table 3. The results of pairwise comparison of Trichinella nativa capsules by the shape index from six carnivore species in the Voronezh State Nature Reserve and its adjacent areas

\begin{tabular}{|c|c|c|c|}
\hline \multicolumn{2}{|c|}{ Host types and species } & \multicolumn{2}{|c|}{ Criteria for the pairwise comparison by the shape index } \\
\hline Host $1 \mathrm{~V}(\mathrm{M} \pm \mathrm{m}(\mathrm{lim}))$ & Host 2 & $\mathrm{t}$ & $\mathrm{p}$ \\
\hline \multirow{5}{*}{$\begin{array}{l}\text { Martes martes } \\
0.70 \pm 0.02(0.54-0.87)\end{array}$} & Meles meles & 3.90 & $<0.001$ \\
\hline & Vulpes vulpes & 8.80 & $<0.001$ \\
\hline & Canis lupus & 3.18 & $<0.001$ \\
\hline & Nyctereutes procyonoides & 8.40 & $<0.001$ \\
\hline & Felis catus & 16.5 & $<0.001$ \\
\hline \multirow{5}{*}{$\begin{array}{l}\text { Meles meles } \\
0.63 \pm 0.01(0.56-0.74)\end{array}$} & Vulpes vulpes & 14.2 & $<0.001$ \\
\hline & Canis lupus & 0.4 & $>0.05$ \\
\hline & Martes martes & 3.9 & $<0.001$ \\
\hline & Nyctereutes procyonoides & 14.3 & $<0.001$ \\
\hline & Felis catus & 26.1 & $<0.001$ \\
\hline \multirow{5}{*}{$\begin{array}{l}\text { Vulpes vulpes } \\
0.88 \pm 0.02(0.74-1.00)\end{array}$} & Canis lupus & 9.60 & $<0.001$ \\
\hline & Martes martes & 8.8 & $<0.001$ \\
\hline & Nyctereutes procyonoides & 0.9 & $>0.05$ \\
\hline & Meles meles & 14.2 & $<0.001$ \\
\hline & Felis catus & 4.7 & $<0.001$ \\
\hline \multirow{5}{*}{$\begin{array}{l}\text { Canis lupus } \\
0.64 \pm 0.02(0.42-0.79)\end{array}$} & Vulpes vulpes & 9.6 & $<0.001$ \\
\hline & Martes martes & 3.18 & $<0.001$ \\
\hline & Nyctereutes procyonoides & 8.8 & $<0.001$ \\
\hline & Meles meles & 0.4 & $>0.05$ \\
\hline & Felis catus & 18.4 & $<0.001$ \\
\hline \multirow{5}{*}{$\begin{array}{l}\text { Nyctereutes procyonoides } \\
0.90 \pm 0.02(0.82-1.00)\end{array}$} & Vulpes vulpes & 0.9 & $>0.05$ \\
\hline & Canis lupus & 8.8 & $<0.001$ \\
\hline & Martes martes & 8.4 & $<0.001$ \\
\hline & Meles meles & 14.3 & $<0.001$ \\
\hline & Felis catus & 3.3 & $<0.001$ \\
\hline \multirow{5}{*}{$\begin{array}{l}\text { Felis catus } \\
0.97 \pm 0.01(0.86-1.00)\end{array}$} & Meles meles & 26.1 & $<0.001$ \\
\hline & Vulpes vulpes & 4.7 & $<0.001$ \\
\hline & Canis lupus & 18.4 & $<0.001$ \\
\hline & Martes martes & 16.5 & $<0.001$ \\
\hline & Nyctereutes procyonoides & 3.3 & $<0.001$ \\
\hline
\end{tabular}

Note: $\mathrm{V}$ - the shape index of Trichinella capsules; $\mathrm{M}$ - mean value; $\mathrm{m}$ - error of the mean; lim - limits of values; $\mathrm{t}$ - Student's t-test; $\mathrm{p}$ - significance level; significantly different pairs are marked in bold.

Table 4. Morphometric study of Trichinella nativa larvae from six carnivore species in the Voronezh State Nature Reserve and its adjacent areas

\begin{tabular}{|c|c|c|c|c|c|c|}
\hline 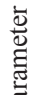 & $\begin{array}{l}\text { Meles meles } \\
\quad(\mathrm{n}=25)\end{array}$ & $\begin{array}{l}\text { Vulpes vulpes } \\
\quad(\mathrm{n}=25)\end{array}$ & $\begin{array}{l}\text { Canis lupus } \\
\quad(\mathrm{n}=25)\end{array}$ & $\begin{array}{l}\text { Martes martes } \\
\quad(\mathrm{n}=25)\end{array}$ & $\begin{array}{l}\text { Nyctereutes procyonoides } \\
\qquad(\mathrm{n}=25)\end{array}$ & $\begin{array}{l}\text { Felis catus } \\
\quad(\mathrm{n}=25)\end{array}$ \\
\hline & \multicolumn{6}{|c|}{$\mathrm{M} \pm \mathrm{m}(\lim ))$} \\
\hline 1 & $\begin{array}{c}967.7 \pm 30.3 \\
(666.7-1267.0)\end{array}$ & $\begin{array}{c}1124.0 \pm 22.6 \\
(888.9-1272.7)\end{array}$ & $\begin{array}{c}1164.9 \pm 32.4 \\
(772.7-1545.5)\end{array}$ & $\begin{array}{c}982.1 \pm 27.9 \\
(809.1-1113.6)\end{array}$ & $\begin{array}{c}1137.0 \pm 19.3 \\
(909.1-1336.4)\end{array}$ & $\begin{array}{c}889.6 \pm 5.98 \\
(845.3-954.5)\end{array}$ \\
\hline 2 & $\begin{array}{l}38.8 \pm 0.87 \\
(28.9-47.6) \\
\end{array}$ & $\begin{array}{r}41.98 \pm 0.95 \\
(34.0-51.0) \\
\end{array}$ & $\begin{array}{c}41.5 \pm 0.8 \\
(34.0-47.6) \\
\end{array}$ & $\begin{array}{c}39.3 \pm 0.4 \\
(37.4-40.8) \\
\end{array}$ & $\begin{array}{l}43.0 \pm 0.69 \\
(39.1-51.0) \\
\end{array}$ & $\begin{array}{l}44.5 \pm 0.27 \\
(40.8-47.6) \\
\end{array}$ \\
\hline 3 & $\begin{array}{c}636.6 \pm 22.7 \\
(400.0-845.0)\end{array}$ & $\begin{array}{l}735.5 \pm 17.76 \\
(590.9-909.1) \\
\end{array}$ & $\begin{array}{c}808.4 \pm 23.1 \\
(545.5-1022.7)\end{array}$ & $\begin{array}{c}662.4 \pm 20.1 \\
(559.1-795.4) \\
\end{array}$ & $\begin{array}{c}775.1 \pm 16.5 \\
(568.2-963.6)\end{array}$ & $\begin{array}{l}592.2 \pm 3.56 \\
(554.6-613.6)\end{array}$ \\
\hline 4 & $\begin{array}{c}339.6 \pm 14.5 \\
(155.5-511.0)\end{array}$ & $\begin{array}{l}388.0 \pm 17.78 \\
(200.0-568.2)\end{array}$ & $\begin{array}{c}362.5 \pm 20.0 \\
(227.3-590.9)\end{array}$ & $\begin{array}{c}319.7 \pm 16.0 \\
(195.5-418.1)\end{array}$ & $\begin{array}{c}361.6 \pm 9.1 \\
(318.2-454.5)\end{array}$ & $\begin{array}{c}297.4 \pm 7.79 \\
(259.1-399.9) \\
\end{array}$ \\
\hline 5 & $\begin{array}{c}479.0 \pm 21.3 \\
(266.6-689.0) \\
\end{array}$ & $\begin{array}{l}535.3 \pm 15.08 \\
(409.1-681.8) \\
\end{array}$ & $\begin{array}{c}648.2 \pm 25.5 \\
(481.8-863.6) \\
\end{array}$ & $\begin{array}{c}553.0 \pm 19.2 \\
(431.8-704.5) \\
\end{array}$ & $\begin{array}{c}624.9 \pm 16.5 \\
(431.8-781.8) \\
\end{array}$ & $\begin{array}{c}481.6 \pm 3.6 \\
(436.4-500.0) \\
\end{array}$ \\
\hline 6 & $49 \pm 1(45-55)$ & $48 \pm 1(45-55)$ & $51 \pm 1(48-57)$ & $54 \pm 1(52-59)$ & $57 \pm 1(54-59)$ & $51 \pm 1(50-52)$ \\
\hline 7 & $\begin{array}{c}153.4 \pm 4.53 \\
(100.0-188.9) \\
\end{array}$ & $\begin{array}{c}200.4 \pm 8.93 \\
(136.4-295.5) \\
\end{array}$ & $\begin{array}{c}160.2 \pm 9.2 \\
(90.9-250.0) \\
\end{array}$ & $\begin{array}{c}109.4 \pm 6.4 \\
(59.1-150.0) \\
\end{array}$ & $\begin{array}{c}150.2 \pm 7.9 \\
(90.9-209.1) \\
\end{array}$ & $\begin{array}{c}110.5 \pm 1.9 \\
(90.9-122.7) \\
\end{array}$ \\
\hline 8 & $\begin{array}{c}326.3 \pm 16.7 \\
(238.6-533.0)\end{array}$ & $\begin{array}{c}369.3 \pm 17.5 \\
(212.0-547.8) \\
\end{array}$ & $\begin{array}{c}340.7 \pm 19.0 \\
(193.3-556.9)\end{array}$ & $\begin{array}{c}294.2 \pm 15.8 \\
(168.3-401.1) \\
\end{array}$ & $\begin{array}{c}339.5 \pm 9.1 \\
(284.2-434.1)\end{array}$ & $\begin{array}{c}265.8 \pm 7.7 \\
(225.1-362.5)\end{array}$ \\
\hline 9 & $\begin{array}{l}20.8 \pm 0.55 \\
(17.0-25.5)\end{array}$ & $\begin{array}{c}18.7 \pm 17.26 \\
(179.6-533.7)\end{array}$ & $\begin{array}{l}21.8 \pm 1.5 \\
(8.5-40.8)\end{array}$ & $\begin{array}{c}25.5 \pm 2.4 \\
(17.0-42.5)\end{array}$ & $\begin{array}{c}22.1 \pm 1.6 \\
(11.9-37.4)\end{array}$ & $\begin{array}{l}31.6 \pm 0.91 \\
(23.8-37.4)\end{array}$ \\
\hline 10 & $\begin{array}{c}316.5 \pm 14.3 \\
(143.6-478.7) \\
\end{array}$ & $\begin{array}{l}365.7 \pm 17.26 \\
(179.6-533.7) \\
\end{array}$ & $\begin{array}{c}331.5 \pm 20.2 \\
(189.9-563.7) \\
\end{array}$ & $\begin{array}{c}294.8 \pm 16.0 \\
(171.7-390.9) \\
\end{array}$ & $\begin{array}{c}312.1 \pm 8.9 \\
(257.0-396.9) \\
\end{array}$ & $\begin{array}{c}259.4 \pm 7.8 \\
(221.7-365.9) \\
\end{array}$ \\
\hline 11 & $\begin{array}{c}21.8 \pm 1.89 \\
(5.1-39.1)\end{array}$ & $\begin{array}{c}22.31 \pm 1.62 \\
(8.5-40.8)\end{array}$ & $\begin{array}{c}31.1 \pm 1.8 \\
(17.0-54.4)\end{array}$ & $\begin{array}{c}24.9 \pm 1.3 \\
(13.6-30.6)\end{array}$ & $\begin{array}{c}49.5 \pm 1.9 \\
(37.4-68.0)\end{array}$ & $\begin{array}{l}38.1 \pm 0.92 \\
(23.8-44.2)\end{array}$ \\
\hline
\end{tabular}

Note: $\mathrm{n}$ - number of the studied larvae from carnivore hosts; $\mathrm{M}$ - mean value; $\mathrm{m}$ - error of the mean; lim - limits of values. Studied parameters: 1 - body length, $\mu \mathrm{m} ; 2$ - body width, $\mu \mathrm{m} ; 3$ - length of the trophic sensory part, $\mu \mathrm{m} ; 4$ - length of the trophic reproductive part, $\mu \mathrm{m} ; 5$ - length of the stichosome, $\mu \mathrm{m} ; 6$ - number of stichocytes, $\mathrm{n} ; 7$ - length of the muscular esophagus, $\mu \mathrm{m} ; 8$ - length of the mid-intestine, $\mu \mathrm{m} ; 9$ - length of the rectum, $\mu \mathrm{m} ; 10$ - length of gonads, $\mu \mathrm{m} ; 11$ - distance from the gonads' beginning to caudal end of larvae, $\mu \mathrm{m}$. 


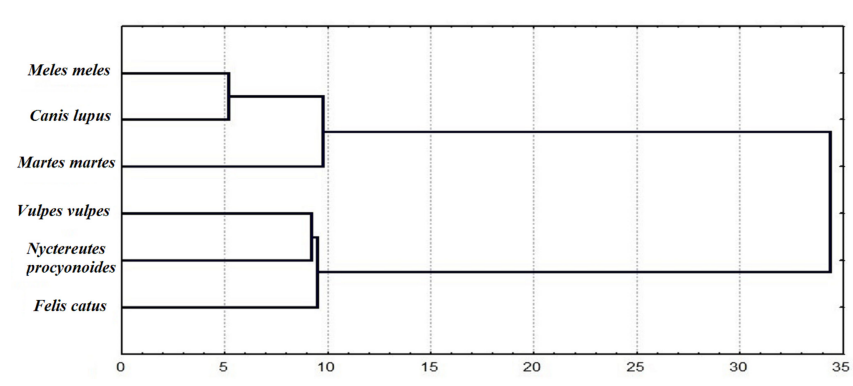

Fig. 5. Dendrogram of comparison of six Carnivora specieshosts of Trichinella nativa based on 12 morphological parameters of larvae using the complex joining method.

The similarity of T. nativa larvae morphs indicates a stable and successful infection of predators in each cluster by trichinellosis. This indicates trophic relationships between host animals (predation, necrophagia, cannibalism) participating in the Trichinella transmission in the VSNR. We determined two groups of trophically similar carnivore species, which exchange Trichinella the most actively: Meles meles - Canis lupus and Vulpes vulpes - Felis catus domestica (Fig. 5). Vulpes vulpes is also more likely to contribute to the sustainable infestation of Nyctereutes procyonoides with $T$. nativa than other hosts.

Thus, there is much carrion, i.e. dead carnivores, on the diet of Nyctereutes procyonoides in the Voronezh State Nature Reserve (Ivanova, 1962). The results of the clustering of the hostal forms of Trichinella reflect the specifics of trophic relationships between individual groups of predators, including the native and alien species) (Fig. 5).

We have confirmed the participation of insects in the Trichinella larvae transmission. Predatory beetles, namely Carabidae species, were identified as disseminators of larvae. Trichinella larvae were found in $28 \%$ of the studied Carabidae beetles. A negative result was obtained for other insects, namely necrophagous beetles and Calliphoridae larvae. The number of invertebrates increased manifold on the decomposing animal body. This is an important trophic factor in the trichinellosis dissemination. Consequently, Trichinella larvae can be transmitted to carnivores and insectivores (i.e. Erinaceus concolor) from Carabidae species. Ivanova (1962) studied the eating habits of Nyctereutes procyonoides, Vulpes vulpes, and Meles meles in the Voronezh State Nature Reserve. The obtained results confirm that in natural environment in the tro- phic chain «mammals $\leftrightarrow$ insects», Trichinella is transmitted by insects.

Below, we present the ecological model of the T. nativa transmission in the VSNR. In the diagram, the host animals are arranged according to their contribution to the preservation of trichinellosis, taking into account the factors of the trichinellosis dissemination (trophic chorological interactions and the number of host animals) (Fig. 6).

Vulpes vulpes is the dominant host which forms the core of the T. nativa parasitic system. This is indicated by the high infection rate and the size of the local Trichinella hemipopulation, as well as by the highest number of Vulpes vulpes compared to other carnivores. The next level is formed by Nyctereutes procyonoides, Meles meles, and Martes martes. The remaining two carnivore species (Canis lupus and Martes foina) are on the periphery (Fig. 6).

On the one hand, the mechanism of the trichinellosis circulation is based on the interactions between the parasite and host populations, and, on the other hand, on the interpopulation and intrapopulation relationships of the hosts, which occur among their food chains. In the VSNR, the main ecological forms of these relationships and Trichinella transmission routes are predation, necrophagy and cannibalism. In addition, Erinaceus concolor and insects (Carabidae) can serve as an important additional source of Trichinella infection (Fig. 6).

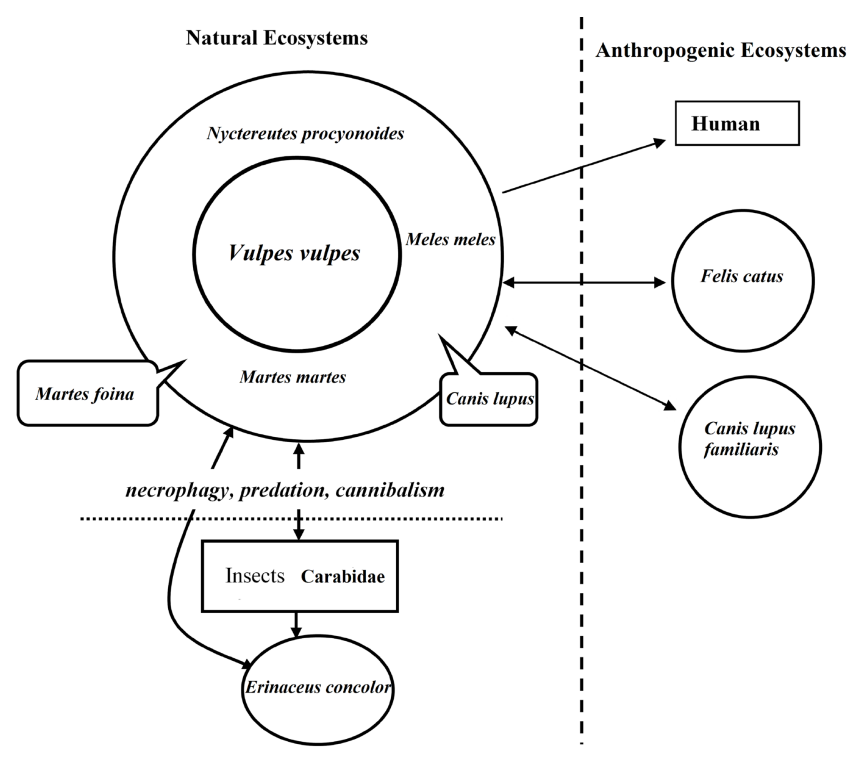

Fig. 6. Ecological model of Trichinella nativa transmission in the Voronezh State Nature Reserve and its adjacent areas. 


\section{Discussion}

The obtained results characterise the features of the biology and ecology of Trichinella in the VSNR. Trichinella nativa was found in mammals, primarily carnivores. This corresponds to the current geographical distribution of this species (Britov, 1982; Pozio \& Murrell, 2006; Gajadhar et al., 2009; Bukina \& Odoevskaya, 2013; Odoevskaya \& Spiridonov, 2016). The study area is located in the centre of European Russia (Black Soil Region) in the forest-steppe zone (Milkov, 1961). Therefore, the obtained results concerning the biology and ecology of $T$. nativa can be extrapolated to the natural conditions of this whole region.

Trichinella nativa is found under natural conditions where carnivores are obligatory (principal) hosts. In the VSNR, T. nativa is found in populations of eight carnivore species. The highest infection prevalence (35.7-70.0\%) was observed in Vulpes vulpes, Nyctereutes procyonoides, Meles meles, and Martes martes.

Our study of over 2000 Sus scrofa specimens from the Voronezh State Nature Reserve for T. nativa gave negative results. The material was obtained during the population control activities in 1980-1990s. Therefore, S. scrofa is not infected with T. nativa and does not transmit this parasite in the Voronezh State Nature Reserve. A number of studies indicate the $T$. nativa phenotypic variations caused by parasitising in non-specific hosts. These variations include morphological changes, lower virulence, fecundity, and resistance and shorter time of parasitism (Odoevskaja et al., 2009; Bukina, 2013).

We examined the relative number (lpg) and distribution of T. nativa larvae in various muscles of carnivores. Consequently, we determined two patterns for the relative number of larvae. In the native carnivore species (Vulpes vulpes and Martes martes), the number of larvae was about $10 \mathrm{lpg}$, while in alien carnivores (Nyctereutes procyonoides and Canis lupus familiaris) there were more than $700 \mathrm{lpg}$. This leads to a higher pathogenicity of trichinellosis. The obtained results allow us to consider Trichinella as a considerable factor in controlling the number of hosts that affects the naturalisation of alien carnivore species in natural conditions.

The results of similar studies revealed similar rates for the relative intensity of $T$. nativa infection in muscle tissue. In the arctic regions, Trichinella was found in Vulpes vulpes (48.5 lpg), Vulpes lagorus (11.8 lpg), and Canis lupus familiaris (90 lpg) (Bukina, 2012b). A considerably lower number of larvae (1.6 lpg) was found in Ursus maritimus Phipps, 1774 (Moorhead et al., 1999). In marine mammals, the number of larvae varied from $0.2 \mathrm{lpg}$ to more $40 \mathrm{lpg}$ (Proulx et al., 2002; Isomursu \& Kunnasranta, 2011; Bukina, 2012a).

An overview of the existing literature showed that similar numbers were registered for predators in European countries. On average, the level of 2-8 lpg is common for Canidae (Vulpes vulpes and Canis lupus) (Krois et al., 2005; Malakauskas et al., 2007; Beck et al., 2009), although in some cases infection rates of 50-200 lpg were registered (Krois et al., 2005; Beck et al., 2009).

Material from carnivores demonstrated an uneven distribution of Trichinella in the muscles and a relatively pronounced «selectivity» in regard to certain muscle groups. Our study showed that the highest relative number of Trichinella (lpg) was observed in the muscle groups of foreleg and hind leg. According to other authors, the muscles of the foreleg and hind leg, masseter, muscles of the tongue and diaphragm are the most actively infested by larvae (Kapel et al., 1995; Belozerov \& Zhdanova, 2000; Kapel, 2000; Zhdanova \& Uspensky, 2002; Bukina et al., 2008; Gajadhar \& Forbes, 2010). Kapel (2000) noted that the parasite distribution in the host's muscles does not depend on the genotype, but it is rather determined by the host type, the period and intensity of infestation by adult Trichinella.

During the comparative morphological study, we noted the host-depending variability of $T$. nativa capsules and larvae. The highest level of variability in Trichinella larvae was found between groups, on the one hand, from local host species, on the other, from alien host species. According to the results of larvae morphs' clustering, trophically close predator groups were identified. Similar studies were conducted in other regions and also demonstrated the adaptive variability of the Trichinella larvae (Britov, 1982; Bukina et al., 2013). A considerable difference was observed in Trichinella between certain carnivore groups, for example, between Canidae and Felidae (Odoevskaja et al., 2009).

Invertebrates can actively contribute to the trichinellosis transmission under natural conditions. Our field experiment, conducted in the Voronezh State Nature Reserve, demonstrated that predatory Carabidae species can disseminate T. nativa larvae. For other insects (necrophagous beetles and Calliphoridae larvae), we obtained negative results. We suggest that further studies are necessary to assess the role of insects as paratenic hosts of Trichinella in the Voronezh State Nature Reserve.

Ecological diversity in certain regions is a determining factor for the species diversity of definitive (intermediate) hosts of Trichinella. Our study 
showed that in the VSNR, the T. nativa transmission is being performed by the carnivore communities represented by six species. The key role belongs to Vulpes vulpes as the dominant host. This demonstrates high rates of the Trichinella infection prevalence and a high index of abundance. In addition, Vulpes vulpes has the largest population in the carnivore community of the VSNR.

Similar results were obtained by other researchers. Vulpes vulpes is the main carrier and disseminator of trichinellosis in the central part of European Russia (Moskvitin et al., 2006; Vagin et al., 2011; Andreyanov, 2012). In Western and Eastern Europe, where Vulpes vulpes also has the largest population among carnivores, it is the dominant host for $T$. britovi, too (Pozio, 1991; Krois et al., 2005; Szell et al., 2008; Blaga et al., 2009; Frey et al., 2009; Hurníková \& Dubinský, 2009; Oivanen \& Oksanen, 2009).

Pozio \& Murrell (2006) suggested that carnivores should be considered as indicators of trichinellosis-contaminated areas. Earlier, Romashov et al. (2006) suggested Vulpes vulpes as a biological object for the trichinellosis monitoring in the Central Black Soil Region. Currently, among wild mammals, Vulpes vulpes is the most widespread and numerous hunting prey in this region. We used $V$. vulpes as an indicator species when we monitored the trichinellosis in the study area.

A high infestation potential of Trichinella (T. nativa and T. britovi) is formed in the wild carnivore community under natural conditions in Europe. As a result, we observe the creation of conditions for transferring causative agents of trichinellosis from natural to anthropogenic conditions. There are two cycles of trichinellosis transmission, including natural and synanthropic cycles (Britov, 1975; Boev, 1978; Pozio, 2001; Pozio \& Zarlenga, 2005; Pozio \& Murrell, 2006). Trichinella spiralis is being transmitted steadily through the synanthropic cycle involving S. scrofa domesticus (Rosenthal, 2008). However, some authors (Pozio \& Zarlenga, 2005; Zarlenga et al., 2006) believe that $T$. spiralis survives to a certain extent due to the natural cycle involving Sus scrofa and carnivores.

Trichinella nativa and T. britovi are being transmitted through the natural cycle involving mainly wild carnivores (Pozio, 2001; Pozio \& Murrell, 2006). The mechanism of the trichinellosis transmission is based on the interactions between the parasite and host populations, and the interpopulation and intrapopulation relationships of the hosts, which occur among their food chains. In the wild, Trichinella is transmitted via nutritional chains of animal hosts, including predation, necrophagy and cannibalism.

\section{Conclusions}

We found that Trichinella nativa, registered in the VSNR, circulates as a natural focal infection. Its obligatory hosts are represented by six species of wild carnivores (Vulpes vulpes, Nyctereutes procyonoides, Canis lupus, Meles meles, Martes martes, and M. foina). Trichinella was also found in Erinaceus concolor and two domestic carnivores (Felis catus and Canis lupus familiaris). The highest infection prevalence was observed in Vulpes vulpes, Nyctereutes procyonoides, Meles meles, and Martes martes (35.7-70.0\%). These hosts play a leading role in the natural trichinellosis transmission.

The carnivores can be divided into two groups according to the infection intensity by Trichinella larvae in the muscles (lpg). The first group included native species (Vulpes vulpes, Canis lupus, Meles meles, Martes martes, and M. foina), with an average of 10 lpg. The second group included alien wild (Nyctereutes procyonoides) and domestic (Felis catus) species, with an average of $700 \mathrm{lpg}$. The lpg of native carnivores is considerably lower than that of alien species. Due to its high infestation rate, Trichinella can be considered as a considerable factor in the regulation of the number of alien carnivores. In the Voronezh State Nature Reserve, Trichinella contributes highly to the Nyctereutes procyonoides naturalisation. Therefore, we can say that under natural conditions, T. nativa protects the ecosystem from alien species invasion.

Trichinella is characterised by an aggregated distribution in the muscles. In the Voronezh State Nature Reserve, carnivores had the highest lpg values in the muscles of the front and rear limbs with over $50 \%$ of the local hemipopulation of Trichinella. We therefore recommend taking samples from the muscles of the front and rear limbs to examine carnivores for trichinellosis.

Evaluation of the morphological characteristics of Trichinella capsules and larvae from carnivores allowed us to identify two clusters of hosts. These clusters comprised carnivore species with closer trophic connections. The variability of the quantitative and qualitative parameters of Trichinella indirectly reflects the specificity of its relations in the parasite-host system by showing the food preferences of the studied carnivores in the Voronezh State Nature Reserve.

Under natural conditions, invertebrates can also transmit trichinellosis. In the Voronezh State Nature Reserve, Carabidae beetles disseminate $T$. nativa. Trichinella can also be transmitted from insects to mammals.

In the VSNR, Vulpes vulpes is the main driver of the stable trichinellosis transmission. Vulpes vulpes 
showed high rates of infection prevalence $(35.7 \%)$ and large Trichinella larvae hemipopulations (3.3 million specimens). Vulpes vulpes is the most abundant species among the carnivores in the Voronezh State Nature Reserve. In addition, this carnivore is the most common hunting prey and can serve as an object for the trichinellosis monitoring in European Russia.

At present, in the VSNR, trichinellosis is being transmitted within the community of wild carnivores. The dominant position in the parasitic system of T. nativa is occupied by Vulpes vulpes, while the other species of carnivorous are subdominant. Erinaceus concolor and Carabidae species can also disseminate Trichinella.

\section{References}

Airas N., Saari S., Mikkonen T., Virtala A.M., Pellikka J., Oksanen A., Isomursu M., Kilpelä S.S., Lim C.W., Sukura A. 2010. Sylvatic Trichinella spp. infection in Finland. Journal of Parasitology 96(1): 67-76. DOI: 10.1645/GE-2202.1

Andreyanov O.N. 2012. The red fox as the main carrier of the causative agent of trichinellosis in the Ryazan Region. Russian Veterinary Journal 4: 20-22. [In Russian]

Andreyanov O.N., Konyaev S.V. 2018. Causative agents of trichinosis in the Central region of Russia. In: Current issues of Parasitology and Ecology. Readings dedicated to the memory of S.S. Shulman: Materials of the All-Russian Scientific Conference with International Participation. Togliatti. P. 28-31. [In Russian]

Asbakk K., Aars J., Derocher A.E., Wiig O., Oksanen A., Born E.W., Dietz R., Sonne C., Godfroid J., Kapel C.M. 2010. Serosurvey for Trichinella in polar bears (Ursus maritimus) from Svalbard and the Barents Sea. Veterinary Parasitology 172(3-4): 256-263. DOI: 10.1016/j.vetpar.2010.05.018

Beck R., Beck A., Kusak J., Mihaljević Z., Lucinger S., Zivicnjak T., Huber D., Gudan A., Marinculić A. 2009. Trichinellosis in wolves from Croatia. Veterinary Parasitology 159(3-4): 308-311. DOI: 10.1016/j.vetpar.2008.10.068

Belozerov S.N., Zhdanova O.B. 2000. Distributions of Trichinella larvae in the muscles of Arctic foxes experimentally infected with $T$. spiralis and comparison of the effectiveness of methods for posthumous diagnosis of trichinellosis. The Eighth All-Russian Conference on Trichinellosis. Moscow. P. 80-85. [In Russian]

Blaga R., Gherman C., Seucom D., Cozma V., Boireau P. 2008. First identification of Trichinella sp. in golden jackal (Canis aureus) in Romania. Journal of Wildlife Diseases 44(2): 457-459. DOI: 10.7589/0090-3558-44.2.457

Blaga R., Gherman C., Cozma V., Zocevic A., Pozio E., Boireau P. 2009. Trichinella species circulating among wild and domestic animals in Romania. Veterinary Parasitology 159(3-4): 218-221. DOI: 10.1016/j.vetpar.2008.10.034

Boev S.N. 1978. Trichinella circulation routes, focality forms and the spread of trichinellosis. In: Trichinella and Trichinellosis. Alma-Ata: Nauka. P. 114-133. [In Russian]
Britov V.A. 1975. Evolution of Trichinella spiralis and the formation of synanthropic foci of trichinellosis in the USSR. In: Second All-Union Conference on Mammals. Moscow. P. 277-279. [In Russian]

Britov V.A. 1982. Causative agents of trichinellosis. Moscow: Nauka. 272 p. [In Russian]

Bukina L.A. 2012a. Role marine mammals in distribution of trichinellosis in Chukotka District. Russian Journal of Parasitology 1: 52-56. [In Russian]

Bukina L.A. 2012b. Trichinella infection in wild terrestrial carnivores, synanthropic and domestic animals in the coastal areas of the Chukchi Peninsula. In: Modern scientific trends in livestock husbandry, hunting and ecology. Kirov. P. 33-36. [In Russian]

Bukina L.A. 2012c. Chironomids and their possible contribution in distribution of trichinellosis in water biocoenoses. Russian Journal of Parasitology 2: 42-46. [In Russian]

Bukina L.A. 2013. The ability of the arctic isolate of Trichinella nativa to adapt to laboratory animals. Russian Journal of Parasitology 4: 18-20. [In Russian]

Bukina L.A. 2014. Gastropods and their participation in transmission of Trichinella spp. in water biocenosis. Russian Journal of Parasitology 2: 26-32. [In Russian]

Bukina L.A., Igitova D.M. 2013. Role of beetles in the spread of Trichinella in aquatic biocenoses. In: Current issues of general parasitology. Moscow. P. 78-81. [In Russian]

Bukina L.A., Odoevskaya I.M. 2013. The epidemiology of trichinosis on the Arctic shores of Chukotka during traditional nature management. Medical Parasitology and Parasitic Diseases 2: 8-13. [In Russian]

Bukina L.A., Kolevatova A.I., Boyarintseva I.Yu. 2008. The Trichinella larvae distribution in the transversus stripe muscle of caged Arctic foxes (the village of Lorino, Chukotsky District). In: Issues of physiology, maintenance, feed production and feeding, and breeding of agricultural animals, biology of fur animals and birds, and hunting. Kirov. P. 55-59. [In Russian]

Bukina L.A., Odoevskaya I.M., Spiridonov S.E., Movsesyan S.O. 2012. Role of dipteran larvae in the transmission of trichinellosisto mammals through infected poultry manure. In: Current issues of general parasitology. Moscow. P. 58-68. [In Russian]

Bukina L.A., Ermolina S.A., Sjutkina A.S., Odoevskaja I.M. 2013. Influence of fermentation on preservation of infective properties of Trichinella nativa larva in traditional food stuffs «Kopalchen» of indigenous population of Chukotka. Russian Journal of Parasitology 1: 28-33. [In Russian]

Frey C.F., Schuppers M.E., Müller N., Ryser-Degiorgis M.P., Gottstein B. 2009. Assessment of the prevalence of Trichinella spp. in red foxes and Eurasian lynxes from Switzerland. Veterinary Parasitology 159(3-4): 295-299. DOI: 10.1016/j.vetpar.2008.10.060

Gajadhar A.A., Forbes L.B. 2010. A 10-year wildlife survey of 15 species of Canadian carnivores identifies new hosts or geographic locations for Trichinella genotypes T2, T4, T5, and T6. Veterinary Parasitology 168(1-2): 78-83. DOI: 10.1016/j.vetpar.2009.10.012

Gajadhar A.A., Gamble H.R. 2000. Historical perspectives and current global challenges of Trichinella and trichinel- 
losis. Veterinary Parasitology 93(3-4): 183-189. DOI: 10.1016/s0304-4017(00)00340-x

Gajadhar A.A., Pozio E., Gamble H.R., Ray Gamble H., Nöckler K., Maddox-Hyttel C., Forbes L.B., Vallée I., Rossi P., Marinculić A., Boireau P. 2009. Trichinella diagnostics and control: Mandatory and best practices for ensuring food safety. Veterinary Parasitology 159(3-4): 197-205. DOI: 10.1016/j.vetpar.2008.10.063

Galaktionov K.V., Dobrovolsky A.A. 1998. The Origin and Evolution of Trematode Life Cycles. St.-Petersburg: Nauka. 404 p. [In Russian]

Gamble H.R., Bessonov A., Cuperlovic K., Gajadhar A.A., van Knapen F., Nöckler K., Schenone H., Zhu X. 2000. International Commission on Trichinellosis: Recommendations on methods for the control of Trichinella in domestic and wild animals intended for human consumption. Veterinary Parasitology 93(3-4): 393-408. DOI: 10.1016/s0304-4017(00)00354-X

Hulebak K.L. 1980. Mechanical transmission of larval Trichinella by arctic crustacea. Canadian Journal of Zoology 58(7): 1388-1390. DOI: 10.1139/z80-189

Hurníková Z., Dubinský P. 2009. Long-term survey on Trichinella prevalence in wildlife of Slovakia. Veterinary Parasitology 159(3-4): 276-280. DOI: 10.1016/j. vetpar.2008.10.056

Ivanova G.I. 1962. Comparison of the diets of the red fox, badger and raccoon dog in the Voronezh State Nature Reserve. In: Materials on the fauna and ecology of animals: scientific notes. Moscow. P. 210-256. [In Russian]

Isomursu M., Kunnasranta M. 2011. Trichinella nativa in grey seal Halichoerus grypus: spill-over from a highly endemic terrestrial ecosystem. Journal of Parasitology 97(4): 735-736. DOI: 10.1645/GE-2717.1

Kapel C.M. 2000. Host diversity and biological characteristics of the Trichinella genotypes and their effect on transmission. Veterinary Parasitology 93(3-4): 263-278. DOI: 10.1016/s0304-4017(00)00345-9

Kapel C.M., Henriksen S.A., Berg T.B., Nansen P. 1995. Trichinella infections in arctic foxes from Greenland: studies and reflections on predilection sites of muscle larvae. Journal of Helminthology 69(4): 325-330. DOI: 10.1017/ s0022149x00014905

Kostin Yu.V. 1977. About methodology of oomorphological researches and unification of descriptions of oological material. In: Methods for researching the productivity and structure of bird species within their areas. Vilnius: Mokslas. P. 14-22. [In Russian]

Krois E., Nöckler K., Duscher G., Joachim A., Kapel C.M.O., Prosl H. 2005. Trichinella britovi beim Rotfuchs (Vulpes vulpes) in Österreich. Wiener Tierarztliche Monatsschrift 92(12): 308-314.

Malakauskas A., Paulauskas V., Järvis T., Keidans P., Eddi C., Kapel C.M., 2007. Molecular epidemiology of Trichinella spp. in three Baltic countries: Lithuania, Latvia, and Estonia. Parasitology Research 100(4): 687-693. DOI: 10.1007/s00436-006-0320-y

Maroli M., Pozio E. 2000. Influence of temperature on the survival and infectivity of Trichinella spiralis larvae in Sarcophaga argyrostoma (Diptera, Sarcophagidae) maggots. Journal of Parasitology 86(3): 633-634. DOI: 10.1645/0022-3395(2000)086[0633:IOTOTS]2.0.CO;2

Merkushev A.V. 1955. On the circulation of trichinellosis invasion in nature and its natural foci. Medical parasitology and parasitic diseases 2: 125-130. [In Russian]

Merkushev A.V. 1965. Study of trichinellosis of wild animals in the USSR. In: Proceedings of the Scientific Conference of the All-Union Society of Helminthologists. Moscow. P. 160-162. [In Russian]

Milkov F.N. 1961. Physical-geographical zoning of the Central Black Earth Regions. Voronezh. 261 p. [In Russian]

Moorhead A., Grunenwald P.E., Dietz V.J., Schantz P.M. 1999. Trichinellosis in the United States, 19911996: Declining But not Gone. American Journal of Tropical Medicine and Hygiene 60(1): 66-69. DOI: 10.4269/ajtmh.1999.60.66

Moskvitin S.A., Sorokin V.N., Moskvitina U.S. 2006. About the spread of trichinellosis among wild animals (the hunted ones) of the Belgorod Region. Herald of Game Management 3(3): 345-349. [In Russian]

Murrell K.D., Lichtenfels R.J., Zarlenga D.S., Pozio E. 2000. The systematics of the genus Trichinella with a key to species. Veterinary Parasitology 93(3-4): 293-307. DOI: 10.1016/S0304-4017(00)00347-2

Odoevskaya I.M. 2011. Significance of birds in the dissemination of Trichinella spp. larvae in coastal and aquatic biocenoses. Medical Parasitology and Parasitic Diseases 1: 12-16. [In Russian]

Odoevskaya I.M., Spiridonov S.E. 2016. Trichinella nativa haplotypes in Russia show diversity in cytochrome oxidase MTDNA gene. Veterinary Parasitology 231: 39-42. DOI: 10.1016/j.vetpar.2016.08.012

Odoevskaja I.M., Khrustalev A.V., Klinkov A.V., Rudenskaja J.A., Filippova I.J., Reshetnikov A.D. 2009. Features of relations parasite-host at experimental infection of laboratory rodents by arctic isolate Trichinella nativa. Russian Journal of Parasitology 3: 30-44. [In Russian]

Odoevskaya I., Uspensky A., Voronin M., Movsesyan S., Bukina L., Panayotova-Pencheva M., Malczewski A., Cabaj W., Shuikina E. 2013. Role of Birds and Invertebrates in Epidemiology and Epizootology of Trichinellosis at Chukotka Seashores. Acta Zoologica Bulgarica 65(4): 531-536.

Oivanen L., Oksanen A. 2009. Synanthropic Trichinella infection in Finland. Veterinary Parasitology 159(3-4): 281284. DOI: 10.1016/j.vetpar.2008.10.057

Oivanen L., Kapel C.M., Pozio E., La Rosa G., Mikkonen T., Sukura A. 2002. Associations between Trichinella species and host species in Finland. Journal of Parasitology 88(1): 84-88. DOI: 10.1645/0022-3395(2002)088[0084:ABTS $\mathrm{AH}] 2.0 . \mathrm{CO} ; 2$

Pérez-Martín J.E., Serrano F.J., Reina D., Mora J.A., Navarrete I. 2000. Sylvatic trichinellosis in southwestern Spain. Journal of Wildlife Diseases 36(3): 531-534. DOI: 10.7589/0090-3558-36.3.531

Pozio E. 1991. The fox (Vulpes vulpes L.) as a principal reservoir of trichinellosis in Italy. Hystrix 3(1): 175-186. DOI: 10.4404/hystrix-3.1-3954

Pozio E. 2000. Factors affecting the flow among domestic, synanthropic and sylvatic cycles of Trichinella. Vet- 
erinary Parasitology 93(3-4): 241-262. DOI: 10.1016/ s0304-4017(00)00344-7

Pozio E. 2001. New patterns of Trichinella infection. Veterinary Parasitology 98(1-3): 133-148. DOI: 10.1016/ s0304-4017(01)00427-7

Pozio E. 2007. World distribution of Trichinella spp. infections in animals and humans. Veterinary Parasitology 149(12): 3-21. DOI: 10.1016/j.vetpar.2007.07.002

Pozio E., Murrell K.D. 2006. Systematics and epidemiology of Trichinella. Advances in Parasitology 63: 367-439. DOI: 10.1016/S0065-308X(06)63005-4

Pozio E., Zarlenga D.S. 2005. Recent advances on the taxonomy, systematics and epidemiology of Trichinella. International Journal for Parasitology 35(11-12): 1191-1204. DOI: 10.1016/j.ijpara.2005.07.012

Pozio E., Casulli A., Bologov V.V., Marucci G., La Rosa G. 2001. Hunting practices increase the prevalence of Trichinella infection in wolves from European Russia. Veterinary Parasitology 87(6): 1498-1501. DOI: 10.1645/0022-395(2001)087[1498:HPITPO]2.0.CO;2

Proulx J., MacLean J.D., Gyorkos T.W., Leclair D., Richter A.K., Serhir B., Forbes L., Gajadhar A.A. 2002. Novel prevention program for trichinellosis in Inuit communities. Clinical Infectious Diseases 34(11): 1508-1514. DOI: $10.1086 / 340342$

Riva E., Fiel C., Steffan P. 2015. The immature stages of Dermestes maculatus, Sarcophaga sp. and Phaenicia sericata as potential paratenic hosts for Trichinella spiralis in nature. Parasitology Research 114(1): 149-154. DOI: 10.1007/s00436-014-4171-7

Romashov B.V., Lomakin V.V. 2000. System of morphological characters in the taxonomy of nematodes of the family Capillariidae (Nematoda, Trichocephlida). In: Topical Issues of General Parasitology. Vol. 42. Moscow: Nauka. P. 175-191. [In Russian]

Romashov B.V., Vasilenko V.V., Rogov M.V. 2006. Trichinellosis in the Central Black Earth Region (Voronezh Region): ecology and biology of Trichinella, epizootology, prevention and monitoring of trichinellosis. Voronezh: Voronezh State University. 181 p. [In Russian]

Romashov V.A. 1959. About trichinellosis of some animal species of the Voronezh Region. In: Proceedings of «Nature Protection of the Central Black Earth Zone». Vol. 2. Voronezh: Voronezh State Nature Reserve. P. 31-36. [In Russian]

Romashov V.A., Lyshov V.F., Romashov B.V. 1980. To the study of the epizootology of trichinellosis in the Voronezh Region. In: Ninth Conference of the Ukrainian Society of Parasitology. Kiev: Naukova Dumka. P. 195-196. [In Russian]

Romashov V.A., Romashov B.V., Gorbunova E.A., Rogov M.V. 2003a. Dangerous hunting trophy. Hunting and hunting industry 3: 24-25. [In Russian]

Romashov V.A., Nepyshnevskaya V.V., Romashov B.V., Rogov M.V., Gorbunova E.A. 2003b. The current situation of trichinellosis in the Voronezh Region. In: Theory and practice of parasitic disease control. Vol. 4. Moscow. P. 355-357. [In Russian]
Rosenthal B.M. 2008. How has agriculture influenced the geography and genetics of animal parasites? Trends in Parasitology 25(2): 67-70. DOI: 10.1016/j.pt.2008.10.004

Schynts F., van der Giessen J., Tixhon S., Pozio E., Dorny P., de Borchgrave J. 2006. First isolation of Trichinella britovi from a wild boar (Sus scrofa) in Belgium. Veterinary Parasitology 135(2): 191-194. DOI: 10.1016/j.vetpar.2005.09.002

Sokolova I.B., Shaikenov B.Sh. 1976. The comparative morphology of Trichinella sibling species. In: Proceedings of the Second All-Union Conference on trichinellosis. Vilnius. P. 95-100. [In Russian]

Solovieva I.A., Bondarenko G.A., Trukhina T.I., Ivanov D.A. 2017. Infection rate of trichinellosis of wild animals in the Amur Region. Bulletin of the Far East Branch of RAS 3(193): 68-70. [In Russian]

Sudarikov V.E. 1971. The phenomenon of amphixenia and its role in the evolution of helminth life cycles. Proceedings of the Helminthological Laboratory of the USSR Academy of Sciences 22: 182-188. [In Russian]

Szell Z., Marucci G., Bajmoczy E., Cseplod A., Pozio E., Sreter T. 2008. Spatial distribution of Trichinella britovi, $T$. pseudospiralis and T. spiralis in red foxes (Vulpes vulpes) in Hungary. Veterinary Parasitology 156(3-4): 210-215. DOI: 10.1016/j.vetpar.2008.06.014

Tulov A.V., Zverzhanovsky M.I., Yanagida T., Konyaev S.V., Andreyanov O.N., Malkina A.V., Odnokurtsev V.A., Bondarev A.Ya., Seryodkin I.V., Esaulova N.V., Nakao M., Sako Y., Ito A. 2013. The species and genetic diversity of Trichinella in canids (Canidae) in Russia. Current issues of veterinary biology 1(17): 35-41. [In Russian]

Uspensky A.V. 2004. Some features of the spread of trichinellosisin Russia. In: Theory and practice of parasitic disease control. Vol. 5. Moscow. P. 68-69. [In Russian]

Uspensky A.V. 2007. Formation and functioning of natural nidus of trichinellosis. Russian Journal of Parasitology 1: 41-45. [In Russian]

Vagin N.A., Malysheva N.S., Samofalova N.A., Dmitrieva E.L. 2011. Studying the patterns of Trichinella circulation in the Kursk Region. Scientific Notes: The online academic journal of Kursk State University 1(18): 39-43. [In Russian]

Vladimirova P.A. 1965. An accelerated method for diagnosis of trichinellosis. Veterinary Medicine 10: 95-96. [In Russian]

Zarlenga D.S., Rosenthal B.M., La Rosa G., Pozio E., Hoberg E.P. 2006. Post-Miocene expansion, colonization, and host switching drove speciation among extant nematodes of the archaic genus Trichinella. Proceedings of the $\mathrm{Na}$ tional Academy of Sciences of the United States of America 103(19): 7354-7359. DOI: 10.1073/pnas.0602466103

Zhdanova O.B., Uspensky A.V. 2002. Studies of experimental trichinellosis in the caged polecat. In: Theory and practice of parasitic disease control. Vol. 3. Moscow. P. 130-133. [In Russian]

Zimmermann W.J. 1970. Trichinosis in the United States. In: S.E. Gould (Ed.): Trichinosis in man and animals. Springfield: C.C. Thomas. P. 378-400. 


\title{
ЭКОЛОГИЧЕСКИЕ ОСОБЕННОСТИ ЦИРКУЛЯЦИИ ТРИХИНЕЛЛЕЗА В ВОРОНЕЖСКОМ ЗАПОВЕДНИКЕ И НА СМЕЖНЫХ ТЕРРИТОРИЯХ (РОССИЯ)
}

\author{
Б. В. Ромашов ${ }^{1,2, *} \mathbb{D}$, И. М. Одоевская ${ }^{3, * *} \mathbb{D}$, Н. Б. Ромашова ${ }^{2, * * *} \mathbb{D}$, Н. А. Голубова ${ }^{1}$ \\ ${ }^{1}$ Воронежский государственный аграрный университет имени императора Петра I, Россия \\ ${ }^{2}$ Воронежский государственный природный биосферный заповедник имени В.М. Пескова, Россия \\ *e-mail: bvrom@rambler.ru,***e-mail: bvnrom@rambler.ru \\ ${ }^{3}$ Всероссийский научно-исследовательский институт \\ экспериментальной ветеринарии имени К.И. Скрябина и Я.Р. Коваленко РАН, Россия \\ **e-mail: odoevskayaim@rambler.ru
}

В статье рассмотрены отдельные аспекты морфологии и биологии трихинелл, экологии и эпизоотологии трихинеллеза в Воронежском заповеднике и на смежных территориях (Центрально-Черноземный регион России). Оригинальные материалы собраны в течение 30 лет (1990-2019 гг.) от потенциальных хозяев трихинелл, преимущественно хищных млекопитающих. За указанный период исследовано свыше 200 особей диких и домашних хищников (Carnivora) трех семейств (Canidae, Mustelidae, Felidae). Облигатными хозяевами являются шесть видов диких хищных млекопитающих: Canis lupus, Vulpes vulpes, Nyctereutes procyonoides, Meles meles, Martes martes, Martes foina. Также трихинеллы обнаружены у Erinaceus concolor и двух видов домашних хищников: Canis lupus familiaris, Felis catus. Наиболее высокая экстенсивность инвазии отмечена у Vulpes vulpes, Nyctereutes procyonoides, Meles meles, Martes martes (35.7-70.0\%). Эти хозяева играют ведущую роль в циркуляции природного трихинеллеза. Среди хищников выделены две группы по интенсивности инфекции личинок трихинелл в мышцах (число личинок на 1 г-lpg). В первую группу входят местные виды хищников (Vulpes vulpes, Canis lupus, Meles meles, Martes martes, M. foina), выявлено в среднем 10 lpg. Во вторую группу входят виды интродуценты (Nyctereutes procyonoides) и виды вселенцы (иммигранты) из антропогенных территорий (Felis catus), у них выявлено в среднем 700 lpg. При высокой патогенности трихинелл мы рассматриваем этих паразитов как весомый фактор регуляции численности чужеродных видов хищников. Для трихинелл отмечено агрегированное распределение в мышцах. В Воронежском заповеднике у хищных выявлены самые высокие показатели lpg в мышцах передней и задней конечностей. Здесь сосредоточено свыше 50\% численности локальной гемипопуляции трихинелл. По оценке морфологических признаков капсул и личинок трихинелл от хищников выделены два кластера хозяев T. nativa. В этих кластерах объединены виды хищников, которые имеют более близкие трофические связи. Гостальная изменчивость количественных и качественных признаков косвенно отражает специфику отношений в системе паразит-хозяин и показывает пищевые предпочтения хищников. В Воронежском заповеднике и на смежных территориях Vulpes vulpes является основным звеном в устойчивой циркуляции природных очагов трихинеллеза. У лисицы выявлены высокие показатели экстенсивности инфекции (35.7\%) и большая численность гемипопуляции личинок трихинелл (3 300000 экз.). Vulpes vulpes - caмый многочисленный вид среди хищников в Воронежском заповеднике и наиболее распространенный объект охоты на сопредельных территориях. Vulpes vulpes может служить объектом мониторинга трихинеллеза в европейской части России. В Воронежском заповеднике циркуляцию трихинеллеза могут поддерживать беспозвоночные животные, в качестве диссеминаторов T. nativa зарегистрированы жуки-карабиды (Carabidae). В настоящее время в Воронежском заповеднике и на смежных территориях трихинеллез циркулирует в сообществе диких хищников. Доминирующее положение в паразитарной системе T. nativa занимает лисица, субдоминантами являются остальные виды хищников. Особенности циркуляции трихинеллеза и факторы передачи трихинелл обусловлены трофическими связями животных-хозяев. Основными формами трофических связей среди хищников являются хищничество, некрофагия и каннибализм. Erinaceus concolor и насекомые (Carabidae) выявлены в качестве дополнительных источников в резервировании и диссеминации трихинелл.

Ключевые слова: Trichinella nativa, Vulpes vulpes, естественная экосистема, индекс формы, морфометрия, популяционная структура, хищные млекопитающие, экстенсивность инвазии 